\title{
Formula Poems for Enriching Writing in the English Classroom
}

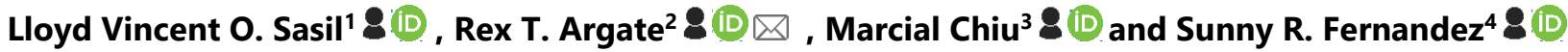 \\ ${ }^{1}$ Faculty, College of Liberal Arts, University of Cebu - Main, Cebu City, Philippines \\ ${ }^{2}$ Chairperson, College of Teacher Education \& Graduate School, University of Cebu - Main, Cebu City, Philippines \\ ${ }^{3}$ Faculty, Graduate School, University of Cebu - Main, Cebu City, Philippines \\ ${ }^{3}$ Faculty, College of Teacher Education, Cebu Normal University - Main, Cebu City, Philippines
}

$\triangle$ Corresponding Author: Rex T. Argate, E-mail: rargate@uc.edu.ph

\begin{tabular}{ll} 
ARTICLE INFORMATION ABSTRACT \\
\hline
\end{tabular}

Received: March 08, 2021

Accepted: April 14, 2021

Volume: 3

Issue: 4

DOI: $10.32996 /$ ijels.2021.3.3.6

\section{KEYWORDS}

Formula poems, freewriting, formula writing, quasi-

experimental
The main objective of the study was to determine the effectiveness of formula poems for enriching writing in the English classroom at the University of Cebu- Main Campus. A quasi-experimental design was used. The experimental group was treated with the use of creative formulae, while the control group was taught to use freewriting. The experts utilized the researcher-made rubric to measure the students' writing performance in both groups. The writing performances of the free writing group had fair rating and there were students got ratings that were also poor. The writing performances of the formula writing group had a very good rating and good ratings which shows that they were better in poetry writing compared to the free writing group. There is a significant difference in the performances of the free writing and formula writing groups. The engagements of the subjects with the formula poems have proved that it is much effective compared to freewriting in assessing the outputs of the subjects. The study concluded that the writing strategy of the students of the formula writing group using formula poems is effective. Furthermore, student writing guided by poetic formulas contributes to more engaged learning and provides a strong framework for creative thinking.

\section{Introduction}

Creativity refers to a person's ability to come up with works that are novel, original, and appropriate. It is considered the topic of a wide scope important in both the individual and societal levels for a wide range of domains. At the level of society, creativity can result in novel scientific findings, original arts, inventions, and social programs. The importance of creativity in our lives includes human civilization which was made possible because of the creative minds of individuals. Inventions, discoveries, and artistic works (beaux arts) characterize human progress with the help of their creative ability in exploration. Human lives have improved a lot from the invention of wheels, cars, aeroplanes, computers, and MacBooks.

Creativity among humans is not recognizable. The music teacher of Beethoven once told him that he is hopeless as a composer. Similarly, the teacher of the inventor Thomas Edison told him he could not learn anything because he is stupid. Though it is difficult to assess creativity, some multiple instruments and assessments have been designed to measure creativity in specific fields such as problem-solving, design, and poetry writing.

In the field of education, the importance of thinking skills makes $K$ to 12 relevant for today's students. There are two types of thinking skills identified: creative thinking and critical thinking. Creative thinking is a thinking skill classified as divergent which seeks multiple solutions to a certain problem or situation. English writing activities develop creative thinking abilities.

As a teacher, the researcher observed that most students find English a source of anxiety both in comprehension and writing. One of the causative factors of this stressful feeling is the textual analysis used in classes. Emphasis on scansion, rhythms and

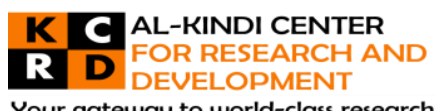

Your gateway to world-class research

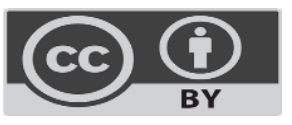

Published by Al-Kindi Center for Research and Development. Copyright (c) the author(s). This open access article is distributed under a Creative Commons Attribution (CC-BY) 4.0 license 
nontextual analysis contribute to this apprehension. Traditional teachers, for convenience and compliance, ask for theme, vocabulary and memorization of the musical lines. Writing, one of the macro skills in language learning, is neglected. Choral reading, one very popular strategy, is fun, but teaching students to write free verses will make them more analytical and creative.

This study is an empirical effort to prove that engaging students to write controlled poems is one effective strategy to make students enjoy reacting to poetic lines, becoming "poets" themselves, and improve their creative intelligence.

\section{Theoretical Background}

This study was anchored in Robert Sternberg's triarchic theory of intelligence. The theory posits the relationship between intelligence and (1) the internal world of the person, or the mental mechanisms behind intelligent behavior; (2) experience, or the mediating role of one's passage through life between his internal and external worlds; and (3) the individual's external world, or how the individual uses his mental mechanisms in everyday life in order to attain an intelligent fit to the environment (Moore, 2012)

The theory comprises three sub-theories. First, the contextual sub theory relates intelligence to the external world of the individual; it addresses the questions of what behaviors are intelligent for whom and of where these behaviors are intelligent. Second, the experiential sub theory relates intelligence to both the internal and external worlds of the individual; it answers the question of when behavior is intelligent. According to the experiential sub theory, intelligent behavior is the purposive adaptation, shaping, and selection of real-world environments relevant to one's life. Rather, one's intelligence is best demonstrated when one is confronted with a relatively novel task or situation; and in the process of automating performance on a given task or in a given situation. Lastly, the componential sub theory relates intelligence to the individual's internal world; it answers the question of how intelligent behavior is generated. In particular, the sub theory specifies the potential set of a mental mechanism that underlies intelligent behavior, regardless of the particular behavioral contents.

If taken as a whole, the three sub theories can help one understand individual differences or who is intelligent. The first, contextual sub theory, is viewed to be relativistic when it comes to the individual and the socio-cultural settings in which he lives. The second, experiential sub theory, is considered relativistic only with regards to the points at which novelty and automatization are relevant for the individual. The third sub theory is universal: Although individuals may differ in what mental mechanisms they apply to a given task or situation, the potential set of mental mechanisms underlying intelligence is viewed to be the same across all individuals and socio-cultural settings (Parry \& Gregory, 1998).

The researcher believes that the starting point for teaching students to write poetry is allowing them to develop experiences and language to describe them. Teachers should integrate poetry into their classroom activities. Students also need to know that poetry is a way of responding to something very real in their lives. Another strategy to encourage students to play with words and start expressing themselves poetically not imposing on them adult standards on writing. A final way of helping students grow in their ability to express themselves through poetry is by introducing carious poetic forms for them to use. The students while appreciating poetry writing should indicate (a) an awareness of an experience, (b) sincerity of feeling, and (c) a choice of appropriate and natural language.

This study strengthens Howard Gardner's theory of multiple intelligences. Human potential can be connected to one's learning preferences; thus, the focus of Gardner on human potential is based on the fact that people have a unique blend of capabilities and skills (intelligences). This model can be used to deeply comprehend an individual's personality, preferences, and strengths and weaknesses. Gardner asserts that people who have an affinity toward one of the intelligence do so in concert with the other intelligences as "they develop skills and solve problems" (Feldman, 2003).

Gardner noted that linguistic intelligence is the pre-eminent human intelligence instance. Language use serves as the primary gatekeepers in schools. Schools have made a lot of assumptions about the learners' intelligence based on their use of language. Thus, it limits their educational opportunities and often crushed their self - esteem. Linguistic intelligence should be viewed as sensitive to the spoken and written word and one's ability to master languages and use them to accomplish specific goals.

A good poet (and thus a linguistically intelligent person) must be sensitive to phonology or the interaction between words. Gardner suggested that it is also necessary to have the capacity to follow the rules of grammar while knowing how to break the rules on selected occasions, such as writing poetry. Poetry comes in many forms. Generally, students have felt that rhyming words are inherent in all poetry. However, this is not always the case. Poetry may be either rhymed or unrhymed.

Rebecca Oxford's language learning strategy theory investigates the impact of enriching poetry class using creative poetic forms. Good language learners use a variety of learning strategies, including cognitive strategies for associating new information with 
existing information in long - term memory and for forming and revising internal mental models; metacognitive strategies for interacting with others and managing discourse; affective strategies for directing feelings, motivations, and attitudes related to learning; and compensation strategies (such as guessing unknown meanings while listening and reading, or using circumlocution in speaking and writing) for overcoming deficiencies in knowledge of the language. Appropriate learning strategies help explain good language learners' performances; similarly, inappropriate learning strategies aid in understanding the frequent failures of poor language learners - and even the occasional weakness of good ones (Mayesky, 2002).

\section{Related Literature}

Thinking is defined as the ability that sets us apart from other species. For practical purposes, thinking can be divided into two major groups: creative thinking and critical thinking. The distinction of these two groups is closely and irrevocably intertwined to one another because creative thinking has critical components and critical thinking has creative elements.

Creative thinking is naturally divergent and seeks multiple solutions to a problem. Thinking creatively is to move outward in many directions from a given situation. There are two ways which the brain can perform this function. Scanning the information that already is stored in long-term memory and seeking new information are the two ways, respectively. Information in longterm memory is stored as a collection of fragments that the brain is able to reassemble into complete memories, facts or concepts. The memory is recalled to working memory differently based on the sequence of steps in which the information is reconstructed. The creative thinker marks the ability to recognize the potential of the connections and capitalize on linking one idea with another unrelated idea, allowing gaining insight and understanding of complex ideas.

Critical thinking is convergent in nature and seeks to narrow the field of options by applying some criteria or evaluation to the data. Convergent compared to divergent, it is to move inward from many points and converge, or focus, a single point. The difference between critical thinking and creative thinking works well in theory. We use both types of thinking by moving from divergence to convergence and back again. Unconsciously, we use both modes of thinking to solve problems, create new technologies, make new artefacts, and establish philosophies (Parry \& Gregory, 1998)

Teachers should be aware that creativity is not as random and accidental as it may seem. The brain cannot connect ideas in which it was not stored on it. Therefore, modern teaching requires engaging activities that can help the learners create significant and relevant ideas. Teachers, therefore, should know the various poetic forms to deliver awareness to students that poetry is not a mere emphasis on rhymes and memorization of lines but rather a creation of ideas, forms and styles.

The poet Kenneth Koch has provided very good scaffolds for writing poetry. He called these formula poems (Tompkins, 2001).

Haiku is a poetic form that originates in Japan. This short poem contains just 17 syllables arranged in three lines of 5, 7 and 5 syllables. The focus of Haiku poems is usually nature and presents a single clear image. Haiku is, much like a telegram because of its conciseness. Because of its brevity, it has been considered an appropriate form of poetry for students to read and write.

Example:

After the bells hummed

and were silent, flowers chimed

a peal of fragrance.

Another related form is diamante, a seven-line contrast poem written in the shape of a diamond. This poetic form helps students apply their knowledge of opposites and parts of speech. The formula is:

Pattern:

Line 1 = Noun

Line 2 = Adjective, Adjective

Line 3 = Verb, Verb, Verb

Line 4 = Noun, Noun, Noun, Noun

Line $5=$ Verb, Verb, Verb

Line 6 = Adjective, Adjective

Line 7 = Noun

Example: 


\author{
Bright, Passionate \\ Charming, Drifting, Growing \\ Gratitude, Infatuation, Antagonism, Irrelevance \\ Abhorring, Falling, Dying \\ Dark, Disgusting \\ Hate
}

Like tanka, a poetic form is a cinquain, a five-line poem containing 5 lines. Cinquains often describe something, but they also tell a story. Have students ask themselves what their subject looks like, smells like, sounds like, and taste like, and record their ideas using a five-senses cluster. The formula is as follows.

Example:

Line 1: name of something or someone

Line 2: two describing words

Line 3: three action words ending with -ing

Line 4: a four word comment about the thing or person

Line 5: a repetition or synonym of line 1

\author{
Candle, \\ Bright, light \\ Glowing, shining, sparkling \\ Such a pretty sight
}

Fire.

Color poem is another type of poetic form in which students begin each line of their poems with a color. They can repeat the same color in each line or choose a different color. In this example, a class of seventh graders writes about yellow:

Example:

\author{
Yellow is shiny galoshes \\ splashing through mud puddles. \\ Yellow is a street lamp \\ beaming through a dark, black night. \\ Yellow is the egg yolk \\ bubbling in a frying pan. \\ Yellow is the lemon cake \\ that makes you pucker your lips. \\ Yellow is the sunset \\ and the warm summer breeze. \\ Yellow is the tingling in your mouth \\ after a lemon drop melts.
}

An acrostic poem is a form in which a student will take a word and write a poem vertically. The writer will write a word or phrase beginning with each letter to complete the poem. Students can write about a book title or a character's name as part of literature focus units.

Example:

$\begin{array}{ll}\text { A } & \text { An acrostic poem } \\ \text { C } & \text { Creates a challenge } \\ \text { R } & \text { Random words on a theme } \\ \text { O } & \text { Or whole sentences that rhyme } \\ \text { S } & \text { Select your words carefully } \\ \text { T } & \text { To form a word from top to bottom } \\ \text { I } & \text { Is the aim of this poetry style } \\ \text { C } & \text { Choose a word then go! }\end{array}$

The five-sense poems require the student to write about a topic using each of the five senses. Sense poems are usually five lines long, with one line for each sense, but sometimes an extra line is added. Students select from the cluster the most vivid or strongest idea for each sense to use in a line of the poem, as this poem written demonstrates: 

a. I see
I see the sage - covered desert.
b. I smel
I smell the freshness of the morning.
c. I hear
I hear the scream of the hawk.
d. I feel
I feel the caress of a breeze.
e. I taste
I taste the dew on the wind.

After you have written out the sentences, remove the pronouns, verbs, and articles as you need to:

Example:

\author{
sage-covered desert \\ freshness of morning \\ scream of the hawk \\ caress of a breeze \\ dew of the wind
}

"If I were ..." poems encourage the writer to make a poem about how they would feel and what they would do if they were something else - a dinosaur, a hamburger, sunshine. They begin each poem with "If I were" and tell what it would be like to be that thing. In composing "If I were. .." poems, students use personification, explore ideas and feelings, and consider the world from a different point of view. In this example, seven-year-old Robbie writes about what he would do if he were a dinosaur:

If I were a Tyrannosaurus Rex

I would terrorize other dinosaurs

And eat them up for supper.

A preposition poem is a form that requires the students to begin each line of a poem with a preposition, and a delightful poetic rewording of lines often results from the attempt. Seventh-grader Mike wrote this preposition poem about a movie super-hero:

Superman

Within the city

In a phone booth

Into his clothes

Like a bird

In the sky

Through the walls

Until the crime

Among us

is defeated

Professor David Starky has also cited other classic poetic forms, namely:

Sonnet is the most well-known example of all many stanza patterns that has organized rhymes. A sonnet is fourteen lines of rhymed iambic pentameter, with varying rhyme schemes.

Example:

Shall I compare thee to a summer's day?

Thou art more lovely and more temperate:

Rough winds do shake the darling buds of May,

And summer's lease hat all too short a date:

Sometimes too hot the eye of heaven shines,

And often is his gold complexion dimmed,

And every fair from fair sometimes decline,

By chance, or nature's changing course untrimmed:

But thy eternal summer shall not fade,

Nor lose possession of that fair thou ow'st,

Nor shall death brag thou wander'st in his shade,

When in eternal lines to time thou grow'st.

So long as men can breathe, or eyes can see,

So long lives this, and this gives life to thee. 
The Shakespearean sonnet or English sonnet means that its three rhyming quatrains - abab cdcd efef- are followed by a final couplet that rhymes gg. Francesco Petrarcha from Italy initiated the mixing and matching of different sonnet rhyme schemes to form a new one with the abbaabba cdecde scheme, which was traditionally called the Petrarchan sonnet.

A villanelle is another popular form originated in France consisting of five tercets and a final quatrain. All these lines should be strictly in iambic pentameter. The first and third lines of the first stanza alternately repeat as the third line in the subsequent tercets. Refrain is the term given to a repeating line or phrase. The villanelle has only two rhymes. The rhyme scheme line by line with the rhyming words in parentheses:

$\begin{array}{ll}\text { 1. } & \text { Refrain 1 (a) } \\ 2 . & \text { (b) } \\ 3 . & \text { Refrain 2 (a) } \\ 4 . & (a) \\ 5 . & (b) \\ 6 . & \text { Refrain 1 (a) } \\ 7 . & (a) \\ 8 . & \text { (b) } \\ 9 . & \text { Refrain 2 (a) } \\ & \\ 10 . & \text { (a) } \\ 11 . & \text { (b) } \\ 12 . & \text { Refrain 1 (a) } \\ 13 . & \text { (a) } \\ 14 . & \text { (b) } \\ 15 . & \text { Refrain 2 (a) } \\ & \\ 16 . & \text { (a) } \\ 17 . & \text { (b) } \\ 18 . & \text { Refrain 1 (a) } \\ 19 . & \text { Refrain 2 (b) }\end{array}$

Example:

And now Chryss Yost's poem, "Escaping from Autopia":

But even leaving, longing to be back,

To do again what I did yesterday-

I, Miss Highway, I couldn't drive off track

or crash. I joined the candy-coated pack

to follow yellow lines and concrete, gray

but even. Leaving. Longing to be back

beyond those lines, in other lines. Like smack these flashback rides, E-ticket crack: You pay you have to stay. I couldn't drive off track,

or spin to face my enemies' attack

The road signs told me "NOW LEAVING L.A."

But even leaving, longing to be back

To go again. I knew I had a knack

For getting there and going. Child's play,

And anyway, I couldn't drive off track,

once safety-strapped onto that strip of black.

I couldn't lose or get lost on the way,

but even leaving, longing to be back 
and be okay. I couldn't drive off track.

Rondeau is another French form heavily reliant on repetition, which has fifteen lines in three stanzas: a quintet, a quatrain, and a sestet. Throughout the poem, two rhyme sounds repeat themselves. The opening words of the first line reappear as a refrain at the end of the second and third stanzas.

The pattern of the lines is as follows, with the rhyming words in parentheses:

\begin{tabular}{|c|c|}
\hline 1. & (a) \\
\hline 2. & (a) \\
\hline 3. & (b) \\
\hline 4. & (b) \\
\hline 5. & (a) \\
\hline 6. & (a) \\
\hline 7. & (a) \\
\hline 8. & (b) \\
\hline 9. & Refrain \\
\hline 10. & (a) \\
\hline 11. & (a) \\
\hline 12. & (b) \\
\hline 13. & (b) \\
\hline 14. & (a) \\
\hline 15. & Refrain \\
\hline
\end{tabular}

Example:

Now McCrae's "In Flanders Fields":

In Flanders fields the poppies blow

Between the crosses, row on row,

That mark our place; and in the sky,

The larks, still bravely singing, fly,

Scarce heard amid the guns below.

We are the dead; short days ago We lived, felt dawn, saw sunset glow, Loved and were loved, and now we lie In Flanders fields.

Take up our quarrel with the foe:

To you from failing hands we throw The torch; be yours to hold it high.

If ye break faith with us who die

We shall not sleep, though poppies grow

In Flanders fields.

The pantoum, another staple of American poetry, came from Malaysia. It consists of any number of quatrains that rhyme abab, with the second and fourth lines of one quatrain repeating as the first and third lines of the following quatrain. Like the villanelle, it requires repeating solid lines with flexible meanings and, in return, provides the poet with a clear structure.

Example:

The way Mother gripped my hair to wind in braids

her blue-veined hands cool and deft

as if remembering a shadow time:

her fault the man had left.

Her blue-veined hands cool and deft

Against my forehead when I lay ill. 
Her fault the man had left, her old mistakes regretted still.

Against my forehead when I lay ill Striped sunlight through venetian blinds. her old mistakes regretted still, no defense could ease the pain

Striped sunlight through venetian blinds like prison bars enclosed my world. No defense could ease the pain. Braided hair bound tight my curls.

Prison bars enclosed my world. Mother's hands that twirled and gripped my hair tight against my head.

No strand escaped or ever slipped.

Mother's hands that gripped and twirled, Hands that seemed both charmed and cruel. My hair tight against my head Yet she would place a ribbon there.

Her hands that seemed both charmed and cruel as if remembering a shadow time, yet she would place a ribbon there despite the way she gripped my hair.

Ghazal is another popular non-Western poem derived from Persian and Urdu sources. Ghazals written in English often break at least one rule of the form; however, Ghazals traditionally consist of five to twelve loosely related but self-contained couplets of approximately the same length; have a melancholy subject, often the hopelessness of an unsatisfied romantic attachment; and repeat the final word or words of the second line at the end of all the second lines.

Example:

-For Jenny and Sasha leaving after Christmas

They are sorting and packing, picking up

Loose ends, toys, ribbons, bits and pieces of the heart.

I am father and grandfather, sitting by,

Letting the sorrow of parting wash into my heart.

Nonna is out doing errands, picking up more

Bits for attention, devotion, pumped along by her heart.

Each year this happens: together for a fortnight we build

A delicately balanced construction, learn it by heart.

Then dismantle it, leaving the floor of the mind flat

While the veins return their used blood to the heart.

Not sorrow, no: fondness. Fondness is all.

We all remember what absence does to the heart.

Given all these formula poems and poetic forms from all parts of the globe, it is but concomitant on the English teacher's part to make the classroom a creative space for learning activities (MacLusky and Cox, 2011). Poetry appreciation is evidently observed in writing. When teachers make activities fun, the classroom offers a wider space for creativity. Writing formula poems is one 
activity that makes students less stressed. Formula poems need no observance of punctuation rules. Students can write about any topic (Trehearne, 2011).

When students are motivated to become divergent thinkers, they will find the classroom relaxing and are likely to become more creative (Mayesky, 2002). Engaging students to be writers of their own experiences through formula verses is one of the stepping stones for classroom use. There is still hope for the English teachers to make students love literature. Imposing on students rhymed verse writing stifles their creativity. When children write poetry, they search for their own voices and need the freedom to do that. Freed from the pressure to create rhyming poetry and from other constraints, children create sensitive word pictures, vivid images and unique comparisons (Tompkins, 2001). Student engagement always involves writing. In English class, poems can be taught. It is a skill that anybody can learn (Feldman, 2003). Engagement is best achieved when the learning climate is friendly to the students. This implies that motivation to learn is very high and autonomy is increasing. How does the teacher achieve this? The instructional skills must be geared towards activities that attract student attention, relevant to the students that keep them involved. Writing formula poems is an example of this instructional variable (Eggen \& Kauchek, 2014).

Therefore, this study will attempt to show the readers that writing in an English class is a lot of fun because it allows students to share a feeling or an experience. It is not enough to make people love listening to rhymes or rhythms of words. Students should be able to speak to other hearts and build images in their minds. The noted Mariane Moore calls poetry "the imaginary gardens with real toads in them." Let this be the springboard for developing the young students' creative skills.

\section{Research Problem}

The study aimed to determine the effectiveness of formula poems for the enrichment of writing for English classes at the College of Teacher Education, University of Cebu - Main Campus. The findings were used as the basis of the proposed action plan.

The study sought answers to the following questions:

1. What are the performances of the two groups of subjects in terms of: 1.1 free writing; and

1.2 formula writing?

2. Is there a significant difference between the performances of the two groups of subjects?

3. Based on the findings, what action plan can be proposed?

\section{Methodology}

The study used the quasi-experimental method in utilizing the performance scores of two groups of literature students belonging to a class where the free style of writing poems is used, and the second class where creative poetic forms are used. The subjects of the study were sixty education students at the University of Cebu - Main. Thirty students served as the control group and the other thirty served as the experimental group. The main instrument that the researcher used was Tita Lacambra Ayala's Cactus as a springboard for the lesson about poetry which has questions to measure the poetry reading comprehension skills of the subjects. The researcher - made rubric provided the criteria: situation, diction, voice, style and unity. The teaching procedure and activity in the first group were performed by means of freestyle poetry writing. The instructional design of creative poetic forms in particular: acrostic, cinquain, diamante, five senses poems and haiku poems highlighted or given the emphasis to enhance the ability of the students in the second group.

The researcher submitted to the dean of the College of Teacher Education a letter requesting permission to conduct the study. Upon the approval of the request, the researcher asked the consent of the subject teacher to enter his classes to get information about the participants which are on age, gender, and midterm grades. After matching the subjects of the two groups, an introduction to poetry was given to each group to measure the students' prior knowledge on the topic. This was given to the two groups on the same day but in different schedules. Then, the topics were introduced to the two groups. A piece entitled "Cactus" was used to elaborate the ideas on poetry and springboard on poetry writing exercises. After the topic was taken up, brainstorming and group sharing were held to emphasize the learners' collaborative learning. The next session, a writing exercise was given to the two groups. The activity was administered to each group on the same day but at different subject encounter time. In the first group, freewriting was used in creating their outputs for the said writing exercise. In the second group, the researcher extended another session for the introduction of formula poems to be used as a strategy in composing their outputs in the said writing activity which would also focus on the criteria given to the first group. In the last session for the second group, creative formulas were employed. Lastly, the outputs were gathered to be assessed by the three experts in literature as identified as Evaluator 1, Evaluator 2 and Evaluator 3 using a researcher-made rubric. 


\section{Results and Discussion}

Performance of the Free Writing Group

Table 1. Performance of the Free Writing Group

\begin{tabular}{|c|c|c|c|c|c|}
\hline Criteria & Evaluator & Mean Rating & Description & $\begin{array}{c}\text { Overall Mean } \\
\text { Rating }\end{array}$ & $\begin{array}{c}\text { Overall } \\
\text { Description }\end{array}$ \\
\hline \multirow{3}{*}{ Situation } & $\# 1$ & 1.23 & Poor & \multirow{3}{*}{2.07} & \multirow{3}{*}{ Fair } \\
\hline & $\# 2$ & 2.80 & Good & & \\
\hline & \#3 & 2.17 & Fair & & \\
\hline \multirow{3}{*}{ Diction } & $\# 1$ & 1.03 & Poor & \multirow{3}{*}{1.80} & \multirow{3}{*}{ Fair } \\
\hline & $\# 2$ & 2.67 & Good & & \\
\hline & $\# 3$ & 1.70 & Poor & & \\
\hline \multirow{3}{*}{ Voice } & $\# 1$ & 1.17 & Poor & \multirow{3}{*}{2.20} & \multirow{3}{*}{ Fair } \\
\hline & $\# 2$ & 2.73 & Good & & \\
\hline & \#3 & 2.70 & Good & & \\
\hline \multirow{3}{*}{ Style } & $\# 1$ & 1.07 & Poor & \multirow{3}{*}{1.93} & \multirow{3}{*}{ Fair } \\
\hline & $\# 2$ & 2.73 & Good & & \\
\hline & \#3 & 2.00 & Fair & & \\
\hline \multirow{3}{*}{ Unity } & $\# 1$ & 1.10 & Poor & \multirow{3}{*}{1.93} & \multirow{3}{*}{ Fair } \\
\hline & $\# 2$ & 2.60 & Good & & \\
\hline & \#3 & 2.10 & Fair & & \\
\hline
\end{tabular}

Table 1 reveals a dismal score in three areas - diction, style, and unity. In the aspect of writing, words are important to convey one's thoughts and feelings. Diction must be appropriate and clear when you write to a person (your audience), about an idea (topic) or to deliver a message (purpose). In spite of the required word limitation, the free writing group shows poor diction which may be a sign of the poor grasp of appropriate words to use because of inadequate vocabulary acquired.

\section{Performance of the Formula Writing Group}

Table 2. Performance of the Formula Writing Group

\begin{tabular}{|c|c|c|c|c|c|}
\hline Criteria & Evaluator & Mean Rating & Description & Overall Mean Rating & Overall Description \\
\hline \multirow{3}{*}{ Situation } & $\# 1$ & 2.57 & Good & \multirow{3}{*}{2.74} & \multirow{3}{*}{ Good } \\
\hline & $\# 2$ & 2.37 & Fair & & \\
\hline & $\# 3$ & 3.30 & Very Good & & \\
\hline \multirow{3}{*}{ Diction } & $\# 1$ & 2.43 & Fair & \multirow{3}{*}{2.50} & \multirow{3}{*}{ Good } \\
\hline & $\# 2$ & 2.33 & Fair & & \\
\hline & \#3 & 2.73 & Good & & \\
\hline \multirow{3}{*}{ Voice } & $\# 1$ & 2.47 & Fair & \multirow{3}{*}{2.70} & \multirow{3}{*}{ Good } \\
\hline & $\# 2$ & 2.33 & Fair & & \\
\hline & \#3 & 3.30 & Very Good & & \\
\hline \multirow{3}{*}{ Style } & $\# 1$ & 2.47 & Fair & \multirow{3}{*}{2.49} & \multirow{3}{*}{ Fair } \\
\hline & $\# 2$ & 2.33 & Fair & & \\
\hline & \#3 & 2.67 & Good & & \\
\hline \multirow{3}{*}{ Unity } & $\# 1$ & 2.43 & Fair & \multirow{3}{*}{2.42} & \multirow{3}{*}{ Fair } \\
\hline & $\# 2$ & 2.23 & Fair & & \\
\hline & \#3 & 2.60 & Good & & \\
\hline
\end{tabular}

Table 2 reveals a good sign of "budding poets" in an ordinary classroom. Criteria 1, the situation has a high mean rating - a sign that creativity is enhanced by formula writing. One of the most recommended tips for writing poetry is to create a springboard this is best illustrated in the use of Koch's suggested poem formulas. Criteria 3 is also quite revealing. Poetry writing is an attempt to interpret some part of life in terms of words. In the formula writing group, the students captured the essence of a feeling stimulated by a particular object of nature - a cactus, puppies, a garden, or a star. 


\section{Writing Performances of the Free and Formula Writing Groups}

Table 3. Writing Performances of the Free and Formula Writing Groups

\begin{tabular}{|c|c|c|c|c|c|}
\hline \multirow{2}{*}{ Rating } & \multirow{2}{*}{ Category } & \multicolumn{2}{c|}{ Free Writing Group } & \multicolumn{2}{c|}{ Formula Writing Group } \\
\cline { 3 - 6 } & & Frequency & Per Cent & Frequency & Per Cent \\
\hline $3.25-4.00$ & Very Good & 0 & 0.00 & 3 & 10.00 \\
\hline $2.50-3.24$ & Good & 1 & 3.33 & 13 & 43.33 \\
\hline $1.75-2.49$ & Fair & 20 & 66.67 & 14 & 46.67 \\
\hline $1.00-1.74$ & Poor & 9 & 30.00 & 0 & 0.00 \\
\hline \multicolumn{2}{|c|}{ Total } & 30 & 100.00 & 30 & 100.00 \\
\hline
\end{tabular}

Table 3 reveals the advantages of formula writing in the classroom. Formulas are good guides for the teacher to help students get organized in their thoughts and "push" their thinking as writers. Formulas make the students' minds more focused on a specific aspect of the writing process - a haiku, for instance, will make them concentrate only on the 17 syllables to be constructed. This will make students utilize more exciting or specific words, more sensory details or more imagery.

When students are motivated to become divergent thinkers, they will find the classroom relaxing and are likely to become more creative (Mayesky, 2002). Writing a poem is a skill which anybody can learn (Feldman, 2003). This is especially true if the instructional skills are geared towards activities that attract students' attention and are relevant to them, which keep them involved. Writing formula poems is an example of this instructional variable (Eggen \& Kauchek, 2014).

\section{Between the Writing Performances of the Free Writing and Formula Writing Groups}

Table 4. Significant Difference between the Writing Performances of the Free Writing and Formula Writing Groups

\begin{tabular}{|c|c|c|c|c|c|c|}
\hline Variables & Mean & Df & Computed Value & Critical Value & Decision on Ho & Interpretation \\
\hline $\begin{array}{l}\text { Writing } \\
\text { Performances of } \\
\text { the Free Writing } \\
\text { Group }\end{array}$ & 1.97 & \multirow[b]{2}{*}{58} & \multirow[b]{2}{*}{6.440} & \multirow[b]{2}{*}{2.002} & \multirow[b]{2}{*}{ Reject Ho } & \multirow[b]{2}{*}{$\begin{array}{c}\text { Significantly } \\
\text { Different }\end{array}$} \\
\hline $\begin{array}{c}\text { Writing } \\
\text { Performances of } \\
\text { the Formula } \\
\text { Writing } \\
\text { Group }\end{array}$ & 2.59 & & & & & \\
\hline
\end{tabular}

The results showed that formula poems could be used to understand individual differences or who is intelligent with respect to both individuals and the sociocultural settings in which they live. The students while appreciating poetry writing indicated the awareness of an experience, sincerity of feeling, and the choice of appropriate and natural language. It also shows that the subjects used learning strategies to aid the acquisition, storage and retrieval of information as it is the initial factor in highlighting the creative thinking skills of an individual.

Table 4 clearly illustrates how important it is for modern educators to tap the potentials of young minds in the learning environment to become real thinkers. Thinking is best stimulated from the motivation of an English teacher to make him or her linguistically intelligent, one aspect explicitly developed by the most recognized educational psychologists, Sternberg and Howard. When teachers make activities fun, the classroom offers a wider space for creativity. Writing formula poems is one activity which makes students less stressed. Formula poems need no observance of punctuation rules. Students can write about any topic (Trehearne, 2011). This study, therefore, affirms the importance of multiple or anarchic intelligence if one wants to be academically successful in life.

Furthermore, the subjects' abilities and potentially tied to one's preferences for learning; thus, it shows that human potential lies in the fact that people have a unique blend of capabilities and skills in writing poetry. The linguistic intelligence of the subjects served as the primary foundation to attain the higher performances of the subject in terms of poetry writing.

\section{Conclusion}

The writing strategy of the students of the formula writing group using formula poems is effective. Using formula poems in their classes, teachers were able to help their students organize their thoughts and think like writers. Formulas help the students 
become more focused on the writing process and utilize interesting words, sensory details, and imagery. Furthermore, student writing guided by poetic formulas contributes to more engaged learning and provide a strong framework for creative thinking.

\section{Recommendations}

In the light of the findings, the following recommendations are given:

1. For future researches on the following topics:

1.1 The use of creative formula writing in translating selected poems written by famous Filipino poets; and

1.2 The integration of real-life experiences in creative formula poetry writing.

2. Adoption of the proposed action plan.

\section{References}

[1] Dymoke, S (2007). The Teaching of Poetry in Secondary Schools. Unpublished PhD thesis: University of Nottingham, UK.

[2] Eggen, P. \& Kauchek, D. (2014). Educational Psychology. England: Pearson Education Ltd.

[3] Feldman, R. (2003). Educational Psychology. Boston: McGraw Hill.

[4] Harrison, B., \& Gordon, H. (1983). Metaphor is thought: Does Northtown Need Poetry? Educational Review, 35(3), $265-278$.

[5] Hughes, J. (2008). The "Screen-Size" Art: Using Digital Media to Perform Poetry. English in Education, 42(2), 148-164.

[6] Long, M. (1989). "Task, Group and Task-Group Interaction". University of Hawaii Working Papers in English as a Second Language, 8. 126

[7] MacLusky, J. and Cox, R. (2011). Teaching Creative Writing. England: McGraw Hill.

[8] Mayesky, M. (2002). Creative Activities for Young Children. Australia: Del Mar Thomson Learning.

[9] Moore, K. (2012). Effective Instructional Strategies. Los Angeles: Sage Publications, Inc.

[10] Nation, I.S.P. and Macalister, J. (2010). Language Curriculum Design. London: Routledge.

[11] Ofsted (2007, July). Poetry in schools: A survey of practice. London: Ofsted. Retrieved December 7, 2009, from http://www.ofsted.gov.uk/Ofstedhome/

[12] Parry, T. \& Gregory, G. (1998). Designing Brain-Compatible Learning. Illinois: Skylight Professional Development.

[13] Ray, R. (1999). The diversity of poetry: How trainee teachers' perceptions affect their attitudes to poetry teaching. The Curriculum Journal, 10(3), 403-418.

[14] Thompson. L. (Ed.). (1996). Teaching of Poetry: European Perspectives. London: Cassell Education.

[15] Tompkins, G. (2001). Literacy in the 21st Century. New Jersey: Mewill Prentice Hall.

[16] Trehearne, M. (2011). Learning to Write and Loving It. California: Corwin Sage Co. 